\title{
PERCEPTION OF THE NEXT GENERATION SCIENCE STANDARD INSTRUCTIONAL PRACTICES AMONG VIETNAMESE PRE-SERVICE AND IN-SERVICE TEACHERS
}

\author{
Nguyen Thi Thuy Hang ${ }^{1,2}$ iD, Niwat Srisawasdi ${ }^{1}$ iD \\ ${ }^{1}$ Faculty of Education, Khon Kaen University (Thailand) \\ ${ }^{2}$ School of Education, Can Tho University (Vietnam) \\ ntthuyhang@ctu.edu.vn,niwsri@kk.ku.ac.th
}

Received November 2020

Accepted June 2021

\section{Abstract}

The STEM education has been emphasized in many countries around the world because of its benefits for students in the new century. In response to the STEM education, Next Generation Science Standard (NGSS) has released a new vision of science education in which learning disciplinary content and crosscutting concepts is to engage science and engineering practices. Thus, science teacher education programs need to have training for pre-service teachers to implement these science and engineering practices. To prepare better for pre-service teachers, it is necessary to know their perception of the science and engineering practices. Besides, understanding in-service teachers' science instruction and principals' direction of teaching at school helps prepare better training. Therefore, this study aims to investigate the perception of pre-service teachers and in-service teachers' implementation of instructional practices aligning with the NGSS approach as well as school principals' views of science teaching. A convergent parallel mixed-method research design was employed in which quantitative data is obtained from a survey of science instructional practices from 187 pre-service teachers and 100 in-service teachers and qualitative data is obtained from interviews of 10 school principals in Can Tho City, Vietnam. The finding indicated that pre-service teachers highly appreciated science and engineering practices in teaching science while in-service teachers' implementation of these practices was lower. In-service teachers tend to use more traditional instruction and incorporate students' prior knowledge in their teaching. Although school principals revealed their appreciation toward teaching science through practices, they admitted that currently, implementation of these practices has been still limited.

Keywords - Next generation science standard, Science and engineering practices, STEM education, Vietnam.

\section{To cite this article:}

Hang, N.T.T., \& Srisawasdi, N (2021). Perception of the next generation science standard instructional practices among Vietnamese pre-service and in-service teachers. Journal of Technology and Science Education, 11(2), 440-456. https://doi.org/10.3926/jotse.1154

\section{Introduction}

Education of science, technology, engineering, and mathematics is called STEM education. The published national reports of many countries had suggested the implementation of STEM education (Ritz \& Fan, 
2015). STEM education has received high attention from many countries around the world because of many reasons. First, in the new industrialized and modernized century, with the advance of new technologies, there is a high demand for a workforce with higher-order thinking skills in science, technology, engineering, and mathematics. Second, many changes may happen in the future with a greater extend such as health crises, and climate change leading to the fact that human beings need to be well equipped in science, technology, engineering, and mathematics literacy. Third, 21st-century learners need to be prepared intern of skills for survival and sustainable development such as critical thinking, cooperation, communication, creativity.

In secondary schools, the STEM education usually focuses on separated parts of STEM such as science and mathematics. However, recently the integration of these four disciplines has gotten more attention from the benefits of learning in authentic contexts. Integrating engineering into science teaching is beneficial in increasing students' motivation, and deeper understanding of science content. Besides, it also enhances their interests into pursuing careers in science, engineering, or technology (Brand, 2020). Engineering applications help students engage in solving real-world problems, enhancing students' skills such as problem-solving, cooperation, and communication. Therefore, engineering has become an essential element in teaching science from the introduction of the Next Generation Science Standards (NGSS Lead States, 2013; Brand, 2020). The Next Generation Science Standards (NGSS) integrated engineering into science education and call for increasing engineering design as the same level of scientific inquiry in science classrooms (Prihati, Sukarmin \& Suryana, 2019). Students are challenged in the scientific works and thought like scientists and engineering to solve authentic problems (Merritt, Chiu, Peters-Burton \& Bell, 2018). NGSS presents a shift from inquiry-based teaching to incorporating authentic scientific practices that reflect the work of scientists (French \& Burrows, 2018). It describes a new vision of American science education for use by all 50 states (Bybee, 2014; Love \& Wells, 2018) in which students' science proficiency gains through the integration of practices with contents. These standards release performance expectations to combine three dimensions (science and engineering practices, crosscutting concepts, and disciplinary core ideas) in a manner that requires students to demonstrate knowledge in use-building and applying scientific knowledge (National Research Council, 2011).

For a long time, the science education community has emphasized the importance of inquiry instruction which contributes to students' learning of contents and practices. The NGSS science and engineering practices originated from inquiry but it is more precisely defined in terms of practices. To learn content, students must engage in the practices, and to learn science and engineering practices, students must involve in content. Disciplinary core ideas and crosscutting concepts can be used by engaging in science and engineering practices. Thus, students have to engage in science and engineering practices to develop and use disciplinary core ideas and crosscutting concepts to explain phenomena and solve problems (Krajcik, Codere, Dahsah, Bayer \& Mun, 2014). Therefore, NGSS places new emphasis on science and engineering practices. Science and engineering practices can be seen as key features of STEM education in teaching science when they link the practice of inquiry with the practice of engineering. For teaching with NGSS, science educators are required to implement science and engineering practices in their instruction.

In Vietnam, to prepare essential competencies for students living in the 21 st century and ready for the fourth industrial revolution, the importance of education has been emphasized in which education of science, technology, engineering, and mathematics (STEM) have been concerned in government documents (Prime Minister, 2017). In direction number 4325/BGDĐT-GDTrH, the Ministry of Education and Training (MOET) instructed "...for secondary education, get ideas of STEM education into the practice of related subjects at the secondary level, implement pilot teaching STEM education at some selected schools" (MOET, 2016). A new secondary school education program has planned implementation in 2020 by the Vietnam Ministry of Education and Training in which scientific practices in teaching science are emphasized such as making question, suggesting hypothesis, making a plan of investigation, conducting experiments, collecting data, analyzing data, presenting and discussion, making conclusion (VietNamNet, 2018). Comparing to the shift of the NGSS, the shift of MOET in teaching 
science had some similarities to the goal that focuses on developing students' competence and more student-centered instruction.

Educational shifts lead to a need for a science teacher education program. Strategies have been suggested for science teacher education programs such as revise elements of, replace components of or reform the program (Bybee, 2014). Bybee (2014) suggested that creating replacement unit or components of the program might include scientific investigation, an introduction to engineering design in which involve undergraduate students with science and engineering practices, crosscutting concepts, and disciplinary core ideas. This change aims to form knowledge and abilities for pre-service teachers who are studying in the final year of the science teacher education program. Basic competencies of the students should include knowledge of the scientific process and cognitive abilities on how to implement a scientific investigation such as the use of models, using evidence as to the basis for arguments, and incorporating engineering design. To actively prepare for future teachers in implementing science and engineering practices, it is necessary to know their perception of these NGSS based science instructional practices. These future teachers will work on new educational reforms at schools very shortly, so understanding the science instruction of in-service teachers who are teaching science at the schools and principals' direction of teaching at these schools is needed which helps prepare better training for pre-service teachers. Therefore, the main purpose of this study is to investigate the pre-service teachers' perception of science instructional practices, practices that in-service science teachers implemented in their teaching, and the science teaching view of school principals. Research questions are as following:

1. How do pre-service teachers understand the importance of NGSS based science instructional practices?

2. What is the level of in-service teachers' implementation of NGSS based science instructional practices at schools?

3. What are school principals' views on the implementation of science teaching?

\section{Literature Review}

\subsection{NGSS and Science and Engineering Practices (SEPs)}

The integration of engineering into science happened in many previous documents such as Benchmarks for Science Literacy (AAAS, 1993), National Science Education Standards (National Research Council, 1996; NGSS Lead States, 2013), but it did not receive high attention as science. Therefore, integration of engineering into science is clearly described in NGSS which raises the importance of engineering as the same status as science in science instruction. The reasons for the integration of engineering into science are that learning needs to address many real-world challenges in front of our life such as energy issues, serious sickness, environmental problems, and clean water sources. These challenges will stimulate students to begin their studies in science and engineering. Besides, students can deepen scientific knowledge by applying their knowledge for solving practical engineering problems. Engineering brings opportunities for students to use what they learn in their daily lives. Therefore, NGSS emphasizes a deeper understanding of science content and a deeper level of scientific and engineering investigation. Learning core ideas through engaging in scientific and engineering practices will help students become less like novices and more like experts. Then students will be well prepared for college, careers, and citizenship. Learning science should reflect the practical nature of science in the real world, so three dimensions of science must be integrated into learning, it does not separate as past science standards (NGSS Lead States, 2013). 
Scientific inquiry has been emphasized as an important strategy of teaching and learning science among the science education community as well as international educational documents (Antink-Meyer \& Brown, 2017; National Research Council, 1996). However, scientific practices were implicit in the inquiry concept, they were not explicitly guided for teachers in teaching in the United States (Antink-Meyer \& Brown, 2017). Therefore, the effort of NGSS (NGSS Lead States, 2013) is to bring a clear and comprehensive description of scientific practices and engineering practices called science and engineering practices, which are specific skills of scientific inquiry and engineering design, to the teachers. Learning core ideas in the context of science and engineering practices help students not only know science concepts but also use their understanding to investigate the natural world and solve meaningful problems. The rationales of the need for science and engineering practices are that engaging in these practices helps students understand how scientific knowledge develops, how the work of engineering is, application of science in the real world or connection between science and engineering, and motivate continuous students' study. NGSS eight practices of science and engineering derived from professional work of scientists and engineers (NGSS Lead States, 2013). They are: 1) asking questions (science) and defining problems (engineering), 2) developing and using models, 3) planning and carrying out investigations, 4) analyzing and interpreting data, 5) using mathematics and computational thinking, 6) constructing explanation (for science) and designing solutions (for engineering), 7) engaging in argument from evidence, 8) obtaining, evaluating, and communicating information.

Practice 1 requires students to be able to ask questions about something they read, phenomena, data, claims, investigation, or conclusions. For engineering, students can ask questions to define problems, generate ideas, testing solutions. In the process of scientific inquiry and engineering design, students can make many questions that lead them to involve in other practices. Practice 2 relates to models. Models consist of diagrams, physical copy, mathematical representation, analogies, and computer simulation. They are not only to represent a system for developing questions, and explanations, but also to collect data and make predictions. For engineering, models are useful in analyzing systems, test solutions, and refine a design. Practice 3 involves students planning and carry out many kinds of investigations including scientific and engineering investigations. In any investigations, students should make clear the purpose, outcomes prediction, and plan of actions that create data for evidence. Practice 4 includes representation of data in a way displaying pattern or relationship which help them communicate with other students. Students can identify important features, use mathematics, and consider reasons for an error of data interpretation. Practice 5 relates to students' ability to use mathematics to represent the relationship of variables, and engage in computational thinking which includes data organization, algorithms, use, and development of new simulations. Practice 6 reflects expectations about constructing scientific phenomena' explanations which consist of a claim of how variables related together and designing solutions which are a process related to identifying a problem, generating, testing, and improving solutions. Practice 7 involves students in argumentation based on evidence to get agreement on the explanation and defense of new ideas. Practice 8 comprises students' ability in reading and create text and view reports in science and engineering. Students can use diverse sources to get information and multiple ways to communicate information (NGSS Lead States, 2013).

\subsection{Previous Studies Related to Science and Engineering Practices}

In response call of NGSS, many kinds of research have been conducted for the implementation of science and engineering practices and integration of three dimensions at many levels (Malkawi \& Rababah, 2018). Plans of instructions and instructional frameworks have been suggested to guide teachers on how to incorporate three dimensions of learning in designing lessons to meet performance expectations (Duschl \& Bybee, 2014; Krajcik et al., 2014). Besides, professional developments have been provided to teachers to implement science and engineering practices in classrooms, and programs for scaling professional development have been suggested (Reiser, Michaels, Moon, Bell, Dyer, Edwards et al., 2017). Research has been conducted to see the influence of professional developments on teachers' implementation of NGSS SEPs. For example, teachers from elementary to high school showed a shift in their instructional practices connecting science and engineering practices with environmental stewardship 
after training participation (Hayes, Wheaton \& Tucker, 2019). There was a significant correlation between the preparation experiences of US technology and engineering teachers and their teaching science content and practices (Love \& Wells, 2018). Second-grade teachers in the US showed significant change by incorporating more practices in their lessons at the end of professional development, however, students got difficulties in practices of argumentation and explanation (Kang, McCarthy \& Donovan, 2019). Luna, Selmer and Rye (2018) suggested that designing teacher learning experiences including a focus on artifacts and what students are doing can enhance ways teachers notice students' thinking in alignment with NGSS SEPs (Luna et al., 2018).

To prepare for professional developments, elementary teachers' pedagogical content knowledge and confidence in implementing NGSS SEPs were explored (Kang, Donovan \& McCarthy, 2018). The results showed that SEP 1 (asking questions and defining problems) and SEP 4 (analyzing and interpreting data) were received a high score, and SEP 5 (using mathematics and computational thinking) was a low score. Similarly, the implementation of NGSS SEPs of science teachers in their teaching was investigated. The research's results indicated that aspects of prior knowledge and traditional instruction are the most scores (Prihati et al., 2019). Malkawi and Rababah (2018) examined the level of SEPs' usage among teaching practices of Jordanian twelfth-grade science teachers. The finding showed that the teachers incorporated SEPs at a moderate level with the lowest occurrence being 'teach a lesson on interpreting statistics or quantitative data'. The results found that science females use SEPs higher frequency than males. Antink-Mayer and Brown (2017) explored relationship of professional history with science and engineering practices in teaching of second-career science teachers who had previous professional backgrounds in STEM fields. The results showed alignment between their professional experience and practices in classroom (Antink-Meyer \& Brown, 2017).

Besides, there are other directions of research related to SEPs. For example, Bielik, Opitz and Novak (2018) used design-based research to examine the development of modeling practice for grade seven students when using an online modeling tool in a unit about water quality (Bielik et al., 2018). French and Burrows (2018) examined preservice science teachers' SEPs in their lesson plans before and after learning secondary science methods courses. Preservice science teachers demonstrated their proficiency in designing learning activities incorporating aspects of SEPs. This finding suggests designing methods courses in science teacher education programs (French \& Burrows, 2018).

The literature review showed that teachers demonstrated a positive change in their teaching practices toward SEPs. However, there were very few studies conducted on pre-service teachers, especially the exploration of their perception of SEPs. In Vietnam, to my best knowledge, the studies investigating pre-service teachers' understanding of NGSS SEPs and what level in-service teachers implemented science instructional practices in their classroom, especially those practices related to NGSS SEPs were very limited. Therefore, this study aims to bring a clear understanding of practices that pre-service teachers hold and in-service teachers done as well as school principals' views about science teaching as a complete picture for good preparation for pre-service teachers.

\section{Methods}

\subsection{Research Design}

This study aims to investigate pre-service teachers' perceptions about science instructional practices in the Physics Teacher Education program, science instructional practices that in-service teachers implemented in their teaching, and the science teaching view of school principals. To get this goal, we used a convergent parallel mixed-method research design (Creswell, 2014), in which both quantitative data and qualitative data are collected, analyzed, and compared together for interpretation. 


\subsection{Participants}

Participants were divided into three samples. Samples 1 included 187 pre-service teachers of the Physic teacher education program, Can Tho University in Mekong Delta, Vietnam. These pre-service teachers were selected using a convenience sampling technique. The pre-service teachers were mainly females with $64.2 \%$, their age mainly ranged from 20 to 22 years old. There was a focus on the third-year and fourth-year students who joined some classes of teaching methods, observation periods, and were preparing an internship at schools. Details of their information are indicated in Table 1. Sample 2 included 100 in-service teachers from 10 public high schools randomly selected in Can Tho city, Vietnam for collecting survey data. The Can Tho city was selected to collect data because the pre-service teachers mainly practiced their internship at the high schools in this area. Therefore, understanding the in-service teachers' implementation of the science practices was necessary to effectively prepare for the pre-service teachers. In-service teachers were selected using the control characteristics sampling technique which selects 10 in-service science teachers per school relating to teaching majors such as Physics, Chemistry, and Biology. The in-service teachers consisted of 69\% females, and there were 38 Physics, 30 Chemistry, 30 Biology, 1 Chemistry and Biology, 1 Technology. Their ages were from 25 to 54 years old in which the number of teachers age over 40 years old was 23, from 30 years old to 40 years old was 63 and under 30 years old was 14, the average age was nearly 37 years old. Almost all in-service teachers had teaching experience in high schools with teaching experience mainly focusing on 6 to 15 years. Details of in-service information were showed in Table 2. Sample 3 for interviews consisted of 10 school principals of 10 high schools that we collected survey data of in-service teachers. They included 7 males and 3 females. The major of six principals were in science such as Physics, Chemistry, and Mathematics. Others majored in Literature and Geography.

\begin{tabular}{|c|c|c|c|c|c|c|c|}
\hline \multirow[b]{2}{*}{$\mathbf{N}$} & \multirow[b]{2}{*}{ Female } & \multicolumn{3}{|c|}{ Major of study } & \multicolumn{3}{|c|}{ Years of study } \\
\hline & & Physics & $\begin{array}{l}\text { Physics- } \\
\text { Technology }\end{array}$ & $\begin{array}{l}\text { Physics- } \\
\text { Information } \\
\text { Technology }\end{array}$ & $\begin{array}{l}\text { Second } \\
\text { year }\end{array}$ & $\begin{array}{c}\text { Third } \\
\text { year }\end{array}$ & $\begin{array}{c}\text { Fourth } \\
\text { year }\end{array}$ \\
\hline 187 & $64.2 \%$ & $80.7 \%$ & $0.5 \%$ & $18.2 \%$ & $5.3 \%$ & $46.5 \%$ & $47.6 \%$ \\
\hline
\end{tabular}

Table 1. Information of sampled pre-service teachers

\begin{tabular}{|c|c|c|c|c|c|c|c|c|c|c|c|}
\hline & & \multicolumn{4}{|c|}{ Major of teaching } & \multicolumn{5}{|c|}{$\begin{array}{c}\text { Average of age } \\
\text { (years old) }\end{array}$} & \multicolumn{4}{c|}{ Teaching experience (years) } \\
\cline { 3 - 11 } & Female & Physics & Chemistry & Biology & Other & $\mathbf{6 - 1 0}$ & $\mathbf{1 1 - 1 5}$ & $\mathbf{1 6 - 1 9}$ & $\mathbf{> 2 0}$ \\
\hline 100 & $69 \%$ & $38 \%$ & $30 \%$ & $30 \%$ & $2 \%$ & 36.81 & $9 \%$ & $30 \%$ & $35 \%$ & $13 \%$ & $13 \%$ \\
\hline
\end{tabular}

Table 2. Information of sampled in-service teachers

\subsection{Instrumentation}

\subsubsection{Survey}

For a survey of science instructional practices, we used a questionnaire developed by Hayes, Lee, DiStefano, O'Connor and Seitz (2016) in investigating teachers' science instructional practices aligned with the NGSS (Hayes et al., 2016). The questionnaire consisted of two parts that part 1 asked about personal information and part 2 included 24 questions covering six areas of instructional practices, with four of these areas linking to the NGSS practices as indicated in Table 3 . The in-service teachers were asked about the level of regularity of activities that they organized in their teaching practices and the regular level of activities that their students did in the learning process on a five-point Likert scale (never, rarely, sometimes, often, and always). The questionnaire for pre-service teachers kept the same as for in-service teachers. However, there was a small revision in the questionnaire that is the regular level of activities that students did in the learning process changed to pre-service teachers' opinion about the importance of practices that teachers and students will do in science teaching in a five-point Likert scale (from 
unimportant to very important) because these pre-service teachers have not yet experienced in science teaching at schools.

Before implementation, to ensure a clear understanding of questions, the instrument was tested with a group of student teachers in the Physics Education program. The instrument was carefully translated from English to Tieng Viet and then a lecturer, a doctor in the science education field, checked the translation and content of questions. The questionnaire was passed to 34 pre-service teachers and they spent 20 minutes finishing the questions. There was not any feedback about the questions which showed that they completely understood the questionnaire. The reliability of measurement is identified by the internal consistency of the instrument or subscales through Cronbach's alpha presented in Table 4 for both groups, pre-service teachers and in-service teachers. The Cronbach's alpha reliabilities of the pre-service teacher group ranged from 0.65 to 0.79 . They were a little lower than Cronbach's alpha of the original study (Hayes et al., 2016), but they were acceptable for all subscales. However, there was high reliability of the subscales in in-service teachers' practice surveys except for the scale "Traditional Instruction". Thus, the instrument ensures reliability and validity for measurement.

\subsubsection{Interviews}

\begin{tabular}{|c|c|c|}
\hline Subscales & & NGSS science and engineering practices \\
\hline \multirow{2}{*}{ Instigating an Investigation } & \multirow{2}{*}{1,3} & Asking questions and defining problems \\
\hline & & Planning and carrying out investigations \\
\hline \multirow{3}{*}{ Data Collection and Analysis } & \multirow{3}{*}{$3,4,5$} & Planning and carrying out investigations \\
\hline & & Analyzing and interpreting data \\
\hline & & Using mathematics and computational thinking \\
\hline \multirow{2}{*}{ Critique, Explanation, and Argumentation } & \multirow{2}{*}{6,7} & Constructing explanations and designing solutions \\
\hline & & Engaging in argument from evidence \\
\hline Modeling & 2 & Developing and using models \\
\hline \multicolumn{3}{|l|}{ Traditional Instruction } \\
\hline Prior Knowledge & & \\
\hline
\end{tabular}

Table 3. Areas of instructional practice and the alignment with the NGSS science and engineering practices

\begin{tabular}{|c|c|c|c|c|c|}
\hline Subscale & $\begin{array}{l}\text { \# of } \\
\text { items }\end{array}$ & Definition & $\begin{array}{l}\text { Hayes et } \\
\text { al. } 2016 \\
\alpha\end{array}$ & $\begin{array}{l}\text { Current study } \alpha 1 \\
\text { for pre-service } \\
\text { teacher group } \\
\quad(N=187)\end{array}$ & $\begin{array}{l}\text { Current study } \alpha 2 \\
\text { for in-service } \\
\text { teacher group } \\
(\mathrm{N}=100)\end{array}$ \\
\hline $\begin{array}{l}\text { Instigating an } \\
\text { Investigation }\end{array}$ & 4 & $\begin{array}{l}\text { Students involve in making } \\
\text { questions, planning and } \\
\text { implementing an investigation }\end{array}$ & 0.79 & 0.68 & 0.76 \\
\hline $\begin{array}{l}\text { Data Collection } \\
\text { and Analysis }\end{array}$ & 5 & $\begin{array}{l}\text { Students collect, analyze, and } \\
\text { interpreting data }\end{array}$ & 0.83 & 0.78 & 0.82 \\
\hline $\begin{array}{l}\text { Critique, } \\
\text { Explanation and } \\
\text { Argumentation }\end{array}$ & 5 & $\begin{array}{l}\text { Students engage in explanation, } \\
\text { argumentation based on evidence }\end{array}$ & 0.88 & 0.73 & 0.92 \\
\hline Modeling & 3 & Students develop and use models & 0.79 & 0.79 & 0.81 \\
\hline $\begin{array}{l}\text { Traditional } \\
\text { Instruction }\end{array}$ & 4 & $\begin{array}{l}\text { The approach is direct, } \\
\text { teacher-based, and focuses on } \\
\text { content, demonstration. }\end{array}$ & 0.74 & 0.67 & 0.49 \\
\hline $\begin{array}{l}\text { Prior } \\
\text { Knowledge }\end{array}$ & 3 & $\begin{array}{l}\text { The instruction that combines } \\
\text { prior knowledge and previous } \\
\text { experience of students }\end{array}$ & 0.83 & 0.65 & 0.81 \\
\hline
\end{tabular}

Table 4. Definition of subscales of science instructional practice survey, original reported and current internal consistency (Cronbach's alpha, $\alpha$ ) (Hayes et al, 2016) 


\begin{tabular}{|c|l|}
\hline $\mathbf{N}$ & \multicolumn{1}{|c|}{ Semi-structured questions } \\
\hline 1 & What is the goal of teaching science in K-12 education? \\
\hline 2 & What do you do to get the goal? \\
\hline 3 & How do you maximize student learning in science classrooms? \\
\hline 4 & How do students learn science best? \\
\hline 5 & How to motivate learning science among students? \\
\hline 6 & What do you think about learning science through solving real-world problems? \\
\hline 7 & What do you do to make learning science more meaningful? \\
\hline 8 & Is it important that learning science through engineering practices, and engineering design of relevant technology? \\
\hline
\end{tabular}

Table 5. Semi-structured questions for the school principals' belief interviews

We developed an interview questionnaire to capture school principals' views of science teaching based on semi-structured questions for teachers' beliefs interviews (Luft \& Roehrig, 2007), which explore science teachers' beliefs on science teaching, and characteristics of STEM education in teaching science that align with NGSS (Radloff \& Guzey, 2016). To enhance the validity of the protocol, two science education experts reviewed it and adjusted some words to make a clearer understanding. After interviewing the school principal 1, we checked the response with the questions for internal consistency and then revised some details on the original version. The final semi-structured questions for school principal interviews are indicated in Table 5.

\subsection{Data Collection}

Data were collected over a month at the beginning of August and the middle of September of 2017. We came to every class for collecting survey data from pre-service teachers. To collect survey data from in-service teachers and school principals, we came to every school, asked help from the principals of that school. To get cooperation from high schools, a letter from Can Tho University introducing our research and a call for data collection help was sent to the school principals. The principals called teachers majoring in Physics, Chemistry, Biology coming to a meeting and they finished the survey at the meeting. Besides, one of two authors contacted these school principals and making interviews at their schools. However, we took difficulty when making interviews with these school principals. Some of the school principals declined to be interviewed because it was a sensitive issue at a time of drastic change in curriculum and teaching methods. As we introduced at the beginning of this paper, a new curriculum is applied at the school year 2020, so currently, schools have to prepare for a change of teaching methods and so on. To make a safe feeling for them that the interview did not affect their individuals as well as their schools, we have printed the interviewed questionnaire and sent it to them. When they read the questions which ask normal issues in science teaching, then they agreed to the interview. The time of each interview was from 30 to 45 minutes which was enough for capturing their views about science teaching regarding the STEM learning approach.

\subsection{Data Analysis \\ 3.5.1. Survey Data}

SPSS 20 was used to analyze survey data in which descriptive statistics including mean, standard deviation draw perception of science instructional practice of pre-service teacher group and practices in-service teachers implementing in their teaching.

\subsubsection{Interviews}

The study used constant comparative methodology (Glaser \& Strauss, 1967) in analyzing interviews and inter-rater reliability based on the procedure that Charmaz suggested (Charmaz, 2006). First, all interviews with school principals were transcribed. Both researchers started independently coding one interview using characteristics of teaching science in NGSS reform (appendix A) (NGSS Lead States, 2013), then they met together and discussed the codes. This coding continued with another interview, each researcher individually coded, then compared and discussed until 90\% agreement among researchers about interpretation and codes. Afterward, all remaining interviews were coded and cross-checked by the researchers. To increase 
trustworthiness, the triangulation of survey data and interviews was used. The result of in-service teachers' implementation of NGSS science instructional practices was checked with the principals' interviews.

\section{Results}

\subsection{Survey}

Table 6 and Figure 1 showed the results from the science instructional practice survey and the meaning of means for both groups. While pre-service teachers evaluated all subscales as "important" and "very important", in-service teachers implemented these practices at a lower level. However, both groups ranked modeling at the lowest score and prior knowledge at the highest score.

Data from in-service teachers showed that prior knowledge was the highest score (3.82), and traditional instruction was the second-highest score (3.7), which revealed that activities of direct, teacher-center instruction and engaging students in prior knowledge and experience usually happen in classrooms. The next highest score was critical, explanation, and argumentation (3.49) which indicated that students often engage in the construction of explanation, and argumentation.

As displayed in Table 6, these instructional practices are related to SEP 6, and SEP 7 in NGSS. The other two scales, instigating an investigation and data collection and analysis, were 2.86 and 2.62, which means that these activities were sometimes organized in classrooms. These two practices connect to SEP 1 , SEP 3, SEP 4, and SEP 5. The lowest rank was modeling (2.23) indicating that issues related to modeling (SEP 2) were rarely implemented in teaching and learning science.

Data from the pre-service teacher survey indicated their high evaluation for all instructional practices. Pre-service teachers evaluated prior knowledge as being very important in teaching science (4.22). The next highest rank was critical, explanation, and argumentation (4.2), which means "important" in teaching practices. Four other instructional practices, which pre-service teachers also valued as "important", were traditional instruction, instigating an investigation, data collection and analysis, and modeling with their scores approximately 4.

Of all subscales, subscales "Traditional instruction, and prior knowledge" are not aligned to any NGSS SEPs. The area of prior knowledge demonstrates the important role of engaging students' prior knowledge and real-world experience in classrooms, which aims to reduce the disadvantages of direct instruction in science learning. Besides inquiry practices, a combination of student epistemologies and a fund of knowledge is necessary to bring a bridge for learning science. The area of traditional instruction seen as direct instruction and focused on content still has its importance in teaching practices. Sometimes, this kind of instruction is essential in scaffold learning concepts and principles that support the process of integrated learning content and practices. However, there is a required balance between traditional and inquiry instruction. As can be seen in Table 6, these two kinds of the instruction received highest scores in implementation in classrooms by in-service teachers and high evaluation by pre-service teachers, which means that these practices were popular in teaching practices. The remaining subscales relate to NGSS SEPs. High scores consisting of SEP 6, 7 (constructing explanations and designing solutions, engaging argument from evidence) mean that they are often implemented in classrooms and also received a high evaluation by pre-service teachers. Next ranks including SEP 1, 3, 4, 5 (asking questions and defining problems, planning and carrying out investigations, analyzing and interpreting data, using mathematics and computational thinking) sometimes happen in classrooms, and the lowest score was SEP 2 (developing and using a model) for both implementation and evaluation. 


\begin{tabular}{|l|c|r|r|c|r|r|r|}
\hline \multirow{2}{*}{ Subscale } & \multirow{2}{*}{$\begin{array}{c}\text { NGSS } \\
\text { SEPs }\end{array}$} & \multicolumn{2}{|c|}{ Pre-service teachers } & \multicolumn{3}{c|}{ In-service teachers } \\
\cline { 3 - 8 } & 1,3 & 3.83 & 0.62 & Important & 2.86 & 0.68 & $\begin{array}{c}\text { Sometimes (once or } \\
\text { twice a month) }\end{array}$ \\
\hline $\begin{array}{l}\text { Instigating an } \\
\text { Investigation }\end{array}$ & $3,4,5$ & 3.83 & 0.63 & Important & 2.62 & 0.71 & $\begin{array}{c}\text { Sometimes (once or } \\
\text { twice a month) }\end{array}$ \\
\hline $\begin{array}{l}\text { Data Collection and } \\
\text { Analysis }\end{array}$ & 2 & 3.62 & 0.84 & Important & 2.23 & 0.74 & $\begin{array}{c}\text { Rarely (a few time a } \\
\text { year) }\end{array}$ \\
\hline $\begin{array}{l}\text { Critical, Explanation } \\
\text { and Argumentation }\end{array}$ & 6,7 & 4.20 & 0.58 & Important & 3.49 & 0.94 & $\begin{array}{c}\text { Often (once or twice } \\
\text { a week) }\end{array}$ \\
\hline Modelling & 2.89 & 0.65 & Important & 3.70 & 0.54 & $\begin{array}{c}\text { Often (once or twice } \\
\text { a week) }\end{array}$ \\
\hline $\begin{array}{l}\text { Traditional } \\
\text { Instruction }\end{array}$ & & 4.22 & 0.62 & Very important & 3.82 & 0.72 & $\begin{array}{c}\text { Often (once or twice } \\
\text { a week) }\end{array}$ \\
\hline Prior Knowledge & & 3 & &
\end{tabular}

Table 6. Mean, SD and meaning of means in science instructional practice survey

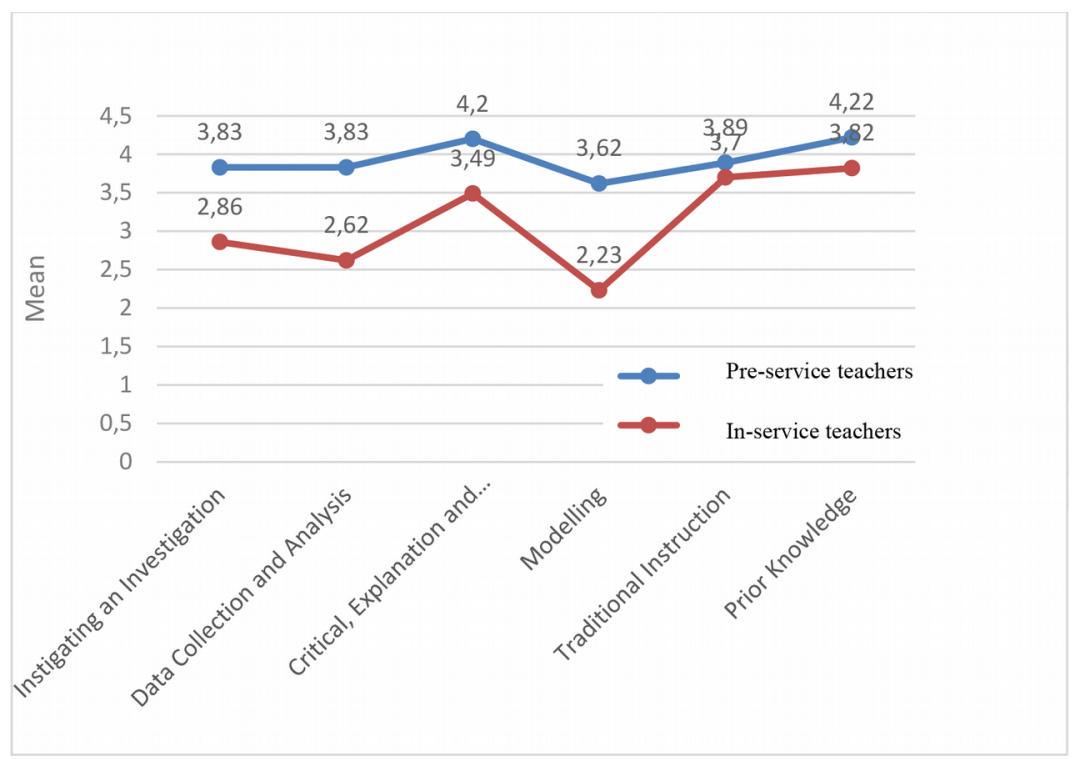

Figure 1. Science instructional practice survey results from pre-service teachers and in-service teachers

\subsection{Interviews}

NGSS emphasized teaching science content through actively engaging science and engineering practices in authentic contexts, which helps students deepen their understanding of the content and application of the knowledge. Besides, increasing engineering as the same level of science in classes provides opportunities to apply students' developing scientific knowledge to solve practical problems, and enhances using what students learn in their daily lives (NGSS Lead States, 2013). How are the views of school principals about science teaching? Are they suitable with the perspectives of the NGSS? Here, the school principals' views are presented into the following categories including goals of science teaching, teaching methods, and factors affecting teaching science.

\subsubsection{Goals of Science Teaching at K-12}

As can be seen in Table 7, almost all school principals presented the goals of science teaching at K-12 which were mainly both scientific knowledge and students' competence of application. Students must develop scientific knowledge and the ability to apply scientific knowledge into daily life including the ability to apply scientific knowledge to explain phenomena and solve real-world problems when they study science in high schools. 
For example,

- Teaching science must provide scientific knowledge for students, provide experiences that help them apply their knowledge.

- The goal of teaching science is to equip scientific knowledge and skills for students. For example, students have skills on how to safely use chemicals, know to guide other people for use, students observe a process of producing products and know a way of evaluating steps of the process...

On the other hand, half of the number of interviewees exhibited that teaching science should develop scientific competence such as skills of planning and investigation, doing experiments.

For example, one principal said that,

- The goal of teaching science is to help students know ways of investigation; ways scientists discover knowledge... know how to check hypothesis by experiments.

Besides, the goal of developing other competence was also concerned such as students' ability of self-learning. Two principals showed views about developing an attitude to the subjects. They said that,

- Teaching science should equip the attitude of loving subjects, make students see the value of the subjects...

- Teaching science should elicit and increase students' interest in science...

\begin{tabular}{|c|c|c|c|}
\hline Theme & Code & $\begin{array}{l}\text { Number of } \\
\text { responses }\end{array}$ & Percentage \\
\hline Scientific knowledge & Provide knowledge to students & 9 & $90 \%$ \\
\hline $\begin{array}{l}\text { Competence of } \\
\text { application }\end{array}$ & $\begin{array}{l}\text { The ability to apply knowledge into daily life including applying } \\
\text { knowledge to explain phenomena, and solve problems }\end{array}$ & 9 & $90 \%$ \\
\hline $\begin{array}{l}\text { Competence of } \\
\text { science subjects }\end{array}$ & $\begin{array}{l}\text { Develop scientific skills such as planning an investigation, } \\
\text { doing experiments } \\
\text { Know ways to implement an investigation }\end{array}$ & 5 & $50 \%$ \\
\hline other competence & Students' ability of self-learning & 1 & $10 \%$ \\
\hline Attitude & interest in science & 2 & $20 \%$ \\
\hline
\end{tabular}

Table 7 . Views about the goals of science teaching of school principals

\subsubsection{Views of Science Teaching}

To maximize students' science learning, school principals concerned with both teachers' teaching methods and factors of external context such as policy, curriculum, parents, infrastructure and equipment at schools, and size of classes. Here firstly, we present the views about teaching methods, then external context.

\subsubsection{Teaching Methods}

The school principals put high importance on teachers and the transformation of teaching methods. As indicated in Table 8, almost all the principals raised the view that teaching science should be through science practices such as doing experiments to test a hypothesis, students' exploration to discover knowledge, learning connecting with practices, or teaching methods that develop student competencies.

The interviewees said that,

- Students should know ways implementation of an investigation to check the hypothesis, learn experimental methods like scientists... 
- Teachers need to let students know processes, methods, ways to create knowledge such as by practices... how to create a clamp...

- Students should explore the knowledge by themselves...increase practices in the classroom... learning by doing... learning connecting with practices...

Besides, all of them emphasized that teaching science should connect to the reality, enhance the application of knowledge into real life. For example, four principals showed their ideas that to improve the use of scientific knowledge in daily life, teachers should organize competitions or diverse forms in which students have opportunities to apply their knowledge such as experience trips in society. Teaching methods require students to apply knowledge to explain phenomena or solve problems.

For example,

- Teachers need to study the application of scientific knowledge then introduce them to students so that students see the usefulness of the knowledge. Increasing their interest in learning...

- Creating projects for students about science and engineering, for example, students look around their schoolyard, and think of using their knowledge to make their school better such as automatic garbage truck, making fertilizer for school plants, making lighting system, vinegar, fire alarm system...

- Organize competitions in which students show an application of their knowledge such as doing practice tests, creating experiments, solving real-world problems.

- Going experience trip in society such as the trip to observe oil extract. Besides, student presentation or a talk of experts about practical fields can enhance connection knowledge into real life.

In summary, almost all interviewees displayed the perspective toward science teaching orienting students' competencies. However, one principal has kept his belief in traditional instruction.

He said that,

- Teaching through practices, or solving real-world problems may apply to only a little content, some contents teachers must lecture because scientists must spend a long time to discover that knowledge.

\begin{tabular}{|l|c|c|}
\hline \multicolumn{1}{|c|}{ Code } & $\begin{array}{c}\text { Number } \\
\text { of responses }\end{array}$ & Percentage \\
\hline $\begin{array}{l}\text { Teaching scientific content through science practices such as doing } \\
\text { experiments, exploration }\end{array}$ & 9 & $90 \%$ \\
\hline Connect teaching scientific knowledge to daily life & 10 & $100 \%$ \\
\hline $\begin{array}{l}\text { Students apply scientific knowledge to explain natural phenomena or } \\
\text { engineering and technology issues or solve real-world problems }\end{array}$ & 4 & $40 \%$ \\
\hline $\begin{array}{l}\text { Organize students' competitions in which students show their application of } \\
\text { scientific knowledge }\end{array}$ & 4 & $40 \%$ \\
\hline Providing activities of experience in real life & 3 & $30 \%$ \\
\hline $\begin{array}{l}\text { After teaching science content, let students' do demonstration experiments } \\
\text { or apply scientific knowledge to solve problems in daily life }\end{array}$ & 1 & $10 \%$ \\
\hline
\end{tabular}

Table 8. Views about teaching science of school principals

When asked about learning science through solving real-world problems, eight of interviewed principals revealed that it is good and necessary. They explained that learning through solving real-world problems enhances students' problem-solving skills, connects learning with reality. Students can explain phenomena, 
discover new problems, and increase their interest in science. However, two principals expressed their opposite ideas about this pedagogy. They thought that it is not necessary because it is difficult to implement in classrooms due to the heavy and fixed curriculum on content, issues of equipment, the teachers' teaching ability, and scores. One interviewee said that they only encourage this teaching approach with cheap and not dangerous products.

Almost all school principals supported learning science through engineering practices and engineering design of relevant products. They thought that it is important because it helps to increase students' interest in science and deepen students' understanding of scientific knowledge. However, some interviewees expressed that making new products is more important because it develops students' creations. For old products, students can search on the internet and imitate. Few principals revealed their thinking that this approach is not necessary because students need to know basic knowledge first. Therefore, teachers need to help students get basic knowledge as a priority, designing products only need to enhance knowledge for little good students. They thought that this approach is good but difficult because the process of making products is very complex in reality. Currently, after teaching science content in classrooms, some teachers have required students to apply knowledge to create products, principals said that. This showed that learning through engineering practices has been still limited at schools, principals tend to focus on real products which are hard to create by doing projects.

The school principals especially expressed their concern to the staff of teachers. They indicated that teachers should identify goals of teaching, improve their major and professional knowledge, enhance their knowledge of application, and their interest in science. Moreover, they showed their thinking about the effect of external factors on getting the goals of teaching.

\subsubsection{The Factor of External Contexts}

Besides the factor of teachers, other external factors also influenced teaching and learning science as indicated in Table 9. School principals revealed that to maximize learning science, the curriculum needs to connect to real life, increase the time of experiments because schools and teachers must comply with the curriculum. Besides, experiment labs need to be increased and the number of students per class should be decreased to 20 students. Learning by practice required more equipment, so the good infrastructure was a factor encouraging teachers to transform their teaching. Besides, learning evaluation affected the teaching methods and learning motivation. Scores had significantly influenced teaching and learning. Students want to get high scores while evaluation mainly focused on content, so it was difficult to transform teaching methods. Parents played an important role in the orientation of children's learning and interest in science. Therefore, to enhance learning science, it was necessary to pay attention to parents. Finally, the directions of school leaders and government policy were crucial to transform teaching and learning.

\begin{tabular}{|l|c|c|}
\hline \multicolumn{1}{|c|}{ Code } & $\begin{array}{c}\text { Number of } \\
\text { responses }\end{array}$ & Percentage \\
\hline Curriculum & 6 & $60 \%$ \\
\hline Experiment lab and equipment & 5 & $50 \%$ \\
\hline Scores and awards & 4 & $40 \%$ \\
\hline Evaluation & 3 & $30 \%$ \\
\hline Size of class & 3 & $30 \%$ \\
\hline Leaders and policy & 1 & $10 \%$ \\
\hline Parents & 1 & $10 \%$ \\
\hline
\end{tabular}

Table 9. External factors affect teaching and learning science

\section{Discussion and Conclusion}

Summary, pre-service teachers highly evaluated the importance of all SEPs in which the highest score was SEP 6 and SEP 7, and the lowest score was SEP 2. Besides, in-service teachers implemented these practices at a lower level in which SEP 2 was rarely conducted in classrooms and SEP 1, 3, 4, 5 were sometimes applied for teaching science. Only SEP 6, 7 were often employed by teachers when teaching. It 
means that the implementation of NGSS science practices in the classroom was less regular than traditional instruction. In-service teachers tended to cooperate with more students' prior knowledge and teacher-centered approach to teaching science. This issue was supported by the sharing of school principals when talking in the interviews. Some school principals shared current teaching situations in their schools in which traditional instruction has prevailed although almost all principals revealed their views about science teaching through science practices, engineering practices, and engineering design as a good teaching approach. A low application of NGSS science and engineering practices in teaching practice can be explained by many external difficulties. These difficulties affected the teaching decisions such as teachers' ability, curriculum, equipment, assessment, scores, parents, and society. Therefore, the principals expressed their high concern toward the staff of teachers. They hoped their teachers get the transformation of both expertise and professional knowledge to adapt to educational reform. Some studies on the implementation of the social constructivist approach for science education at primary level in Vietnam (Hằng, Meijer, Bulte \& Pilot, 2015) or constructivist learning environment in a Physics Teacher Education program, Mekong Delta, Vietnam (Thao-Do, Bac-Ly \& Yuenyong, 2016) may contribute a better understanding about science teaching and implementation of the science practices in schools.

The result of this study on in-service teachers' implementation of NGSS science practices is quite similar to the result of Frihati et al.'s study in Indonesia (Prihati et al., 2019) in which the implementation of NGSS science practices is less than traditional instruction. In contrast, the implementation of NGSS science practices is more popular in other countries. For example, the study in Jordan (Malkawi \& Rababah, 2018), Jordanian twelfth-grade science teachers used these practices in their teaching at a moderate level in which practices of "using the diagram, table or graphic through instructions and discuss with students how to interpret the quantitative data from the experiment or investigation" are frequently.

Although the implementation of the NGSS science practices did not maximize in high schools, there are some important positive factors that will help the successful usage of these practices. First, in-service teachers implemented SEPs 6, 7 (Critique, Explanation, and Argumentation) regularly and they aware of the use of these practices in their teaching instructions, except SEPs 2 (modeling). Besides, the principals sharply supported teaching transformation, especially science and engineering practices. This is a big advantage for the implementation of these science practices because they are school leaders, their opinions and views strongly affect teachers' teaching decisions. Second, future teachers, the pre-service teachers, had positive thinking of NGSS practices through their high evaluation of these practices. However, the pre-service teachers also highly evaluated traditional instruction and prior knowledge in science teaching. Therefore, the results of this study suggest that it is necessary to organize workshops about these new science practices for both in-service teachers and pre-service teachers. These workshops will help them deeper understand these practices including what they are, the importance of these practices in science learning, the difference between new science teaching practices and traditional instruction. This understanding will help in-service teachers and future teachers cooperate better in teaching with the new standards. Finally, understanding pre-service teachers' perception of instructional practices and level of in-service teachers' implementation of SEPs in classrooms as well as views of school principals with factors influencing decision teaching are useful for next research about training pre-service teachers or professional development for in-service teachers in incorporation more SEPs in classrooms.

\section{Declaration of Conflicting Interests}

The authors declared no potential conflicts of interest with respect to the research, authorship, and/or publication of this article.

\section{Funding}

The authors received financial support for the research from the KKU scholarship for ASEAN and GMS countries' Personnel in the year 2016-2018. 


\section{References}

AAAS- American Association for the Advancement of Science (1993). Benchmarks for science literacy. Oxford University Press. Retrieved from: https://scholar.google.com/scholar lookup?title=Benchmarks $\% 20$ for $\% 20$ science $\% 20$ literacy\&publication year $=1993$

Antink-Meyer, A., \& Brown, R.A. (2017). Second-career science teachers' classroom conceptions of science and engineering practices examined through the lens of their professional histories. International Journal of Science Education, 39(11), 1511-1528. https:// doi.org/10.1080/09500693.2017.1338787

Bielik, T., Opitz, S., \& Novak, A. (2018). Supporting Students in Building and Using Models: Development on the Quality and Complexity Dimensions. Education Sciences, 8(3), 149.

https://doi.org/10.3390/educsci8030149

Brand, B.R. (2020). Integrating science and engineering practices: Outcomes from a collaborative professional development. International Journal of STEM Education, 7(1), 13. https://doi.org/10.1186/s40594-020-00210-x

Bybee, R.W. (2014). NGSS and the Next Generation of Science Teachers. Journal of Science Teacher Education, 25(2), 211-221. https://doi.org/10.1007/s10972-014-9381-4

Charmaz, K. (2006). Constructing grounded theory: A practical guide through qualitative analysis. SAGE.

Creswell, J.W. (2014). Research design: Qualitative, quantitative, and mixed methods approaches (4th ed.). SAGE Publications.

Duschl, R.A., \& Bybee, R.W. (2014). Planning and carrying out investigations: An entry to learning and to teacher professional development around NGSS science and engineering practices. International Journal of STEM Education, 1(1), 12. https://doi.org/10.1186/s40594-014-0012-6

French, D.A., \& Burrows, A.C. (2018). Evidence of Science and Engineering Practices in Preservice Secondary Science Teachers' Instructional Planning. Journal of Science Education and Technology, 27(6), 536-549. https://doi.org/10.1007/s10956-018-9742-4

Glaser, B.G., \& Strauss, A.L. (1967). The discovery of grounded theory: Strategies for qualitative research. Aldine Transaction. https://doi.org/10.1097/00006199-196807000-00014

Hằng, N.V.T., Meijer, M.R., Bulte, A.M.W., \& Pilot, A. (2015). The implementation of a social constructivist approach in primary science education in Confucian heritage culture: The case of Vietnam. Cultural Studies of Science Education, 10(3), 665-693. https://doi.org/10.1007/s11422-014-9634-8

Hayes, K.N., Lee, C.S., DiStefano, R., O’Connor, D., \& Seitz, J.C. (2016). Measuring Science Instructional Practice: A Survey Tool for the Age of NGSS. Journal of Science Teacher Education, 27(2), 137-164. https://doi.org/10.1007/s10972-016-9448-5

Hayes, K.N., Wheaton, M., \& Tucker, D. (2019). Understanding teacher instructional change: The case of integrating NGSS and stewardship in professional development. Environmental Education Research, 25(1), 115-134. https://doi.org/10.1080/13504622.2017.1396289

Kang, E.J.S., Donovan, C., \& McCarthy, M.J. (2018). Exploring Elementary Teachers' Pedagogical Content Knowledge and Confidence in Implementing the NGSS Science and Engineering Practices. Journal of Science Teacher Education, 29(1), 9-29. https://doi.org/10.1080/1046560X.2017.1415616

Kang, E.J.S., McCarthy, M.J., \& Donovan, C. (2019). Elementary Teachers' Enactment of the NGSS Science and Engineering Practices. Journal of Science Teacher Education, 30(7), 788-814.

https://doi.org/10.1080/1046560X.2019.1630794 
Krajcik, J., Codere, S., Dahsah, C., Bayer, R., \& Mun, K. (2014). Planning Instruction to Meet the Intent of the Next Generation Science Standards. Journal of Science Teacher Education, 25(2), 157-175. https://doi.org/10.1007/s10972-014-9383-2

Love, T.S., \& Wells, J.G. (2018). Examining correlations between preparation experiences of US technology and engineering educators and their teaching of science content and practices. International Journal of Technology and Design Education, 28(2), 395-416. https:/ / doi.org/10.1007/s10798-017-9395-2

Luft, J.A., \& Roehrig, G.H. (2007). Capturing Science Teachers’ Epistemological Beliefs: The Development of the Teacher Beliefs Interview. Electronic Journal of Science Education, 11(2), 26.

Luna, M.J., Selmer, S.J., \& Rye, J.A. (2018). Teachers' Noticing of Students' Thinking in Science Through Classroom Artifacts: In What Ways Are Science and Engineering Practices Evident? Journal of Science Teacher Education, 29(2), 148-172. https://doi.org/10.1080/1046560X.2018.1427418

Malkawi, A.R., \& Rababah, E.Q. (2018). Jordanian twelfth-grade science teachers' self-reported usage of science and engineering practices in the next generation science standards. International Journal of Science Education, 40(9), 961-976. https:// doi.org/10.1080/09500693.2018.1460695

Merritt, E.G., Chiu, J., Peters-Burton, E., \& Bell, R. (2018). Teachers' Integration of Scientific and Engineering Practices in Primary Classrooms. Research in Science Education, 48(6), 1321-1337. https://doi.org/10.1007/s11165-016-9604-0

MOET (2016). Official correspondence 4325/BGDDT-GDTrH. https://moet.gov.vn/giaoducquocdan/giao-ductrung-hoc/Pages/chi-tiet-van-ban-chi-dao-dieu-hanh.aspx?ItemID=2058

National Research Council (1996). National science education standards. National Academies Press.

National Research Council (2011). A Framework for K-12 Science Education: Practices, Crosscutting Concepts, and Core Ideas. The National Academies Press.

NGSS Lead States (2013). Next Generation Science Standards: For States, By States. National Academies Press. https://doi.org/10.17226/18290

Prihati, F., Sukarmin, S., \& Suryana, R. (2019). Teachers' Experiences in Implementing the Next Generation Science Standard Science Engineering Practice. Proceedings of the 3rd Asian Education Symposium (AES 2018). Bandung, Indonesia. https://doi.org/10.2991/aes-18.2019.24

Prime Minister (2017). Instruction 16/CT-TTg. http://vanban.chinhphu.vn/portal/page/portal/chinhphu/hethongvanban? class $\mathrm{id}=2 \&$ mode $=$ detail\&document $\mathrm{id}=189610$

Radloff, J., \& Guzey, S. (2016). Investigating Preservice STEM Teacher Conceptions of STEM Education. Journal of Science Education and Technology, 25(5), 759-774. https://doi.org/10.1007/s10956-016-9633-5

Reiser, B.J., Michaels, S., Moon, J., Bell, T., Dyer, E., Edwards, K.D. et al. (2017). Scaling Up Three-Dimensional Science Learning Through Teacher-Led Study Groups Across a State. Journal of Teacher Education, 68(3), 280-298. https://doi.org/10.1177/0022487117699598

Ritz, J.M., \& Fan, S.C. (2015). STEM and technology education: International state-of-the-art. International Journal of Technology and Design Education, 25(4), 429-451. https://doi.org/10.1007/s10798-014-9290-z

Thao-Do, T.P., Bac-Ly, D.T., \& Yuenyong, C. (2016). Learning Environment in Vietnamese Physics Teacher Education Programme Through the Lens of Constructivism: A Case Study of a State University in Mekong Delta Region, Vietnam. International Journal of Science and Mathematics Education, 14(S1), 55-79. https:/ / doi.org/10.1007/s10763-014-9585-2 
VietNamNet (2018). New secondary school programs. VietNamNet.

https://vietnamnet.vn/vn/giao-duc/khoa-hoc/cong-bo-27-chuong-trinh-mon-hoc-pho-thong-moi-497236.html

Published by OmniaScience (www.omniascience.com)

Journal of Technology and Science Education, 2021 (www.jotse.org)

\section{(c) $(1)(8)$}

Article's contents are provided on an Attribution-Non Commercial 4.0 Creative commons International License. Readers are allowed to copy, distribute and communicate article's contents, provided the author's and JOTSE

journal's names are included. It must not be used for commercial purposes. To see the complete licence contents, please visit https://creativecommons.org/licenses/by-nc/4.0/. 